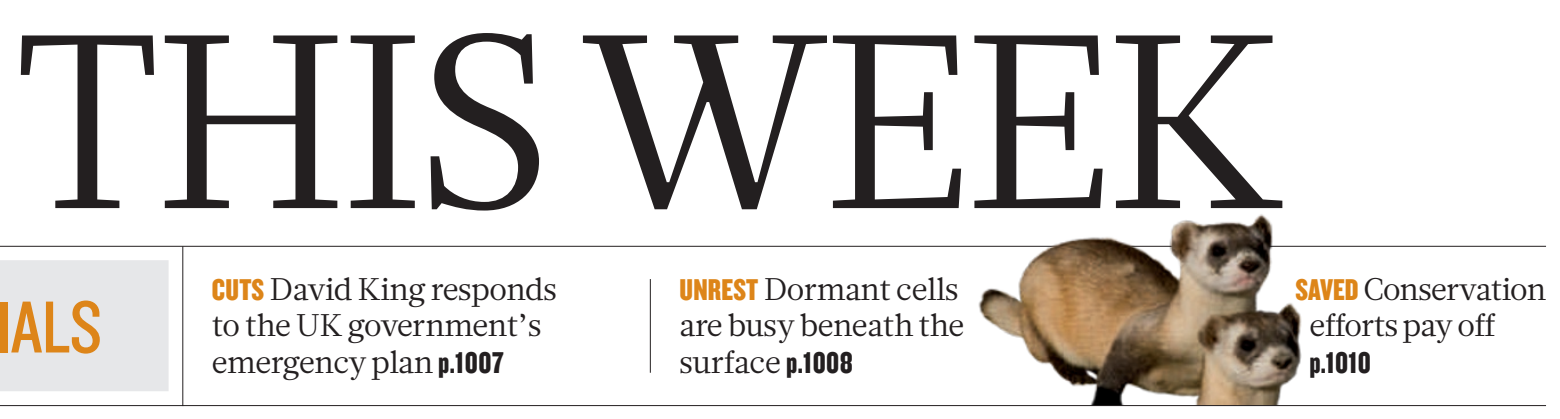

EDITORIALS to the UK government's emergency plan $\mathbf{p . 1 0 0 7}$ are busy beneath the surface $\mathbf{p} .1008$

\title{
The innovation game
}

\section{Innovation within the European Union is wanting for reasons cultural, historical and technical. It can best be strengthened by breaking down barriers and building a united research area.}

A week is a long time in politics, as one-time British prime minister Harold Wilson famously said. But in European Union (EU) politics, a decade can seem very short indeed.

Just look at the ten-year strategic plan for economic growth and improved welfare that EU heads of state signed up to in Lisbon in 2000, in which research had a central role. The three EU bodies - the Council, Parliament and Commission - each realized the urgent need to make Europe work as a single territory for scientists, rather than separate bordered countries - now numbering 27 - with their own languages and habits. They agreed to create the European Research Area, intended to free the movement of scientists between countries by breaking down barriers such as difficulties in transferring pensions or transporting national research grants. They endorsed the concept of a single patent that would be valid EU-wide. And they agreed on a target to spend 3\% of gross domestic product on research and development by 2010 .

But ten years didn't prove long enough to achieve these aims. Once home, national governments were unwilling to concede sufficient sovereignty. The European patent, for example, depends on an agreement to work in a limited number of languages to keep patenting costs reasonable - but sev-

\section{The European Commission is right to emphasize the role of the European Investment Bank.} eral countries still insist that all documents be translated into their own languages. Others want to protect the revenues of their national patent shops. Little headway has been made towards the legislative changes in areas such as pensions that were required to build the European Research Area. And most nations have failed to significantly increase their public research spending, or to incentivize that of the private sector.

Fortunately, the European Commission has stuck to each of these fundamental goals in its latest proposal for a research-related strategy for the next decade, which was released on 6 October. Called the Innovation Union, the new strategy is a component of the Lisbon Agenda's successor, Europe 2020, which was launched in March (see Nature 464, 142; 2010). The EU Competitiveness Council, which comprises national research and industry ministers, is now preparing a response to the Innovation Union document, which will be discussed by the heads of state at a summit meeting on 16 December.

The Commission is dead right to persist with the research objectives of the Lisbon Agenda, because until these are achieved, Europe will not be able to compete. It is also right to emphasize the role of the European Investment Bank in providing much-needed cross-border risk capital, which is barely available in Europe.

Less convincing, unfortunately, is its fresh proposal for what it calls 'innovation partnerships' - elaborate-sounding efforts to engineer alliances between everyone in the innovation chain, all the way from researchers and manufacturers to consumer representatives, to tackle big societal problems. These partnerships will focus on a set of established 'grand challenges', such as the ageing society, climate change and food security. The first of the new partnerships will address 'healthy ageing, the Commission suggests.

If this sort of approach sounds familiar, that's because a number of related ones are already under way. Within one called 'joint programming, for example, national research efforts are supposed to be coordinated independently of the Commission. Another idea, for 'joint technology initiatives', set up public-private research partnerships, cofunded by the Commission. And the European Institute of Innovation and Technology has morphed into another series of public-private partnerships called Knowledge and Innovation Communities.

None of these initiatives can yet be considered successful - they are in their infancy and still being fine-tuned. The innovation partnerships will perpetuate - and further complicate - the tradition, and even aim to tap into public services and their budgets, which are unfamiliar territory for EU research partnerships.

The Healthy Ageing innovation partnership has the remarkably ambitious target of yielding a two-year increase in the age to which the average EU citizen enjoys good health, by 2020. The target is laudable and simple. But is the general strategy correct? It may take many more years to create the European Research Area, but this is really what matters. In the meantime it would be best to get existing initiatives to work better before adding new ones. Once the legislative problems are solved, and risk-capital mechanisms in place, innovation should emerge on its own - without having to engineer it.

\section{Not quite assured}

\section{An upbeat assessment of phosphate reserves leaves several questions unanswered.}

$\mathrm{P}$ hosphorus in the form of phosphate has a crucial involvement in RNA, DNA and cellular metabolism, and all forms of life depend on it. Along with nitrogen and potassium, phosphorus is essential for healthy plant growth - and its supply through fertilizer is a mainstay of modern agriculture.

Reserves of the phosphate rock used to make such fertilizers are finite, and concerns have been raised that they are in danger of exhaustion. It has been argued, for example, that data from the US Geological Survey point to the available supplies peaking in as little as 25 years time (see Nature 461, 716-718; 2009). Because there is no substitute for phosphate in agriculture, this might present an 
urgent and substantial problem. But initial findings from the World Phosphate Rock Reserves and Resources study conducted this year by the IFDC, an international non-profit organization based in Muscle Shoals, Alabama, and formerly known as the International Fertilizer Development Center, suggest that phosphate rock deposits should last for between 300 and 400 years.

Accurate information about phosphate reserves is hard to come by, and the IFDC concedes that more work is needed to hone its estimates. The mining industry, governments and interested researchers should accept the organization's invitation to collaborate in this process.

The phosphate issue runs beyond gaining assurances that total global supply will meet demand. There remain important concerns that phosphate and other fertilizers are being squandered in some parts of the world, whereas farmers in other regions cannot obtain them at a reasonable cost.

After decades of wanton overuse, farmers in the United States, Europe and elsewhere are now using sophisticated assessments to tell them when, how much and in what proportion fertilizer should be applied. That has led to a flattening out in global demand for phosphate fertilizer, despite continued growth in food production.

But elsewhere in the world, especially in Asia, farmers are still applying fertilizer in excess (see Nature doi:10.1038/news.2010.498; 2010). At the same time, farmers in the poorest countries such as some in Africa, find fertilizer prices inflated to unaffordable levels by high transportation costs and local market conditions.

In addition, current fertilizer-production methods fail to maximize the efficient conversion of phosphate rock into fertilizer. The supply of the rock is heavily concentrated in two nations, China

and Morocco, on whose good faith the rest of the world relies for its phosphate supplies. That faith has been shaken by extreme price fluctuations in recent years.

Yet the heavy dependence of food production on fertilizers, inequalities of supply and the need for sustainable use of fertilizers - includ-

"The need for sustainable use of fertilizers is largely missing from discussions on approaches to sustainable development." cussion will be devoted to the topic at the Crop World 2010 meeting in London next week, in which researchers will be joined by industry and government representatives, including John Beddington, the UK government's chief scientific adviser, who has worked hard to raise political awareness of food-security issues.

These efforts would be strengthened if an international body, such as the UN Food and Agriculture Organization, started to seriously champion the issue of sustainable fertilizer use. The organization already tracks fertilizer demand and supply, and has produced reports on phosphate fertilizer use. It doesn't have a specific programme for sustainable fertilizers, but its departments of agriculture and natural resources do some work in this area, giving it a base on which to build. It now needs to push this issue out from the sidelines and into the policy-making process that will shape the future of agriculture and sustainable development.

\section{Space hitch-hiker Commercial spacecraft with room to carry experiments could give science a lift.}

A study on the environmental impacts of space tourism suggests that a surge in private access to space could speed global warming. Led by Martin Ross, an atmospheric scientist at the Aerospace Corporation in El Segundo, California, it shows that sooty emissions from 1,000 rocket launches per year would add as much to climate change as current emissions from the global aviation industry. It has been accepted for publication by Geophysical Research Letters.

Perhaps the most striking aspect of the study is not the projected impact on polar temperature and sea ice, but the size of the industry it models. Three launches a day? Don't bet against it. Barely a decade after US multimillionaire Dennis Tito paid around US\$20 million for a trip to the International Space Station (ISS), space tourism, at least the suborbital type, seems poised for serious lift-off.

The private spaceflight industry is making steady progress. Spaceport America, a launch site in Las Cruces, New Mexico, opened its first runway last week. Earlier this month, US President Barack Obama signed into law the NASA Authorization Act, which, subject to approval by Congress, will see the agency hand over $\$ 15$ million a year to help commercial suborbital efforts.

NASA is keen because it sees what many space scientists have been slow to realize: such suborbital flights could carry research payloads. Virgin Galactic, a pioneer of space tourism, has already indicated that it would be happy to host scientific experiments on its SpaceShipTwo vehicle. A number of fields including atmospheric, space and microgravity research could benefit. A closer relationship with scientists could help the industry in return,

\section{DNATURE.COM} To comment online, click on Editorials at: go.nature.com/xhunqv through work to quantify and reduce its environmental impact, for instance.

A strong advocate of closer ties between rocketeers and researchers is Alan Stern, a planetary scientist at the Southwest Research Institute in San Antonio, Texas, and a former NASA associate administrator, who chairs the Suborbital Applications Researchers Group of the Commercial Spaceflight Federation in Washington DC. Stern says that private suborbital vehicles will be a game-changer for science, because of low costs and the high number of flights. Earlier this year, his group organized the first conference to promote the benefits of private space flights to scientists. A second event is scheduled for February 2011 at the University of Central Florida in Orlando.

Space scientists who wish to fly experiments currently face high costs and long waits for room on the ISS or sounding rockets, or frustratingly brief periods of microgravity in drop-tubes or parabolic aircraft (known with little affection by those who have been aboard as 'vomit comets'). Suborbital flights could offer several minutes of weightlessness for a fraction of the cost of a conventional launch. And the experiments could be supervised by scientists able to fly alongside their kit. An early winner could be the search for vulcanoids asteroids that orbit the Sun closer than Mercury. None has yet been discovered, perhaps because observing them from the ground or highaltitude flights is so awkward.

Although NASA has been quick to identify and nurture the potential of space-tourism operators, others have been more sluggish to recognize their potential. The European Space Agency, for example, has an official position on private suborbital flights only of "cautious interest and informed support". Countries outside the United States have not yet taken the necessary legal steps to open their skies to private operators. Perhaps this reflects scepticism about whether the endeavour will reach the necessary economy of scale, which depends on the number of tourists who sign up. That is a reasonable position at this stage, but space scientists and administrators should drop any snobbish objections they have to the private sector. Those who do not embrace the possibilities could find themselves, quite literally, left behind. 